\title{
Treatments to improve the aeolian sand foundation in solar park construction
}

Xiaosong Xie PhD

Senior Engineer, Shanghai Electric Power Generation Engineering Co. Shanghai, China

\section{Haijun Zhu ME}

Senior Engineer, East China Electric Power Design Institute Co. Ltd of China Power Engineering Consulting Group, Shanghai, China

Jianhua Xiao PhD

Assistant Research Fellow, Key Laboratory of Desert and Desertification, Northwest Institute of Eco-Environment and Resources, Chinese Academy of Sciences, Lanzhou, China
Hui Zhao ME

Senior Engineer, Shanghai Electric Power Generation Engineering Co.,

Shanghai, China

Can Chen PhD

Senior Engineer, Shanghai Electric Power Generation Engineering Co. Shanghai, China

Zhengyi Yao PhD

Research Fellow, Key Laboratory of Desert and Desertification, Northwest Institute of Eco-Environment and Resources, Chinese Academy of Sciences, Lanzhou, China (corresponding author: yaozy@|zb.ac.cn)

The aeolian sand in the Mohammad bin Rashid Al Maktoum (MBR) Solar Park Phase IV Project site in Dubai, United Arab Emirates, is cohesionless, uniformly graded, non-plastic fine sand, with high permeability, low shear strength and low bearing capacity, which are properties that cause many geotechnical and structural challenges. With aeolian sand used as backfill soil, sandstone and sabkha (gatch, gypsum) excavated during field levelling were used as sand fixation material to improve the aeolian sand foundation. In a field compaction test, the compaction method, moisture content, paving thickness, number of rolling passes, backfill layer deformation, compaction coefficient and California bearing ratio were analysed to summarise the technological aspects of the compaction process. Rolling greatly improved the aeolian sand foundation, achieving the required capacity for various projects. The surface layer was stabilised by sandstone-gatch, which had the strongest resistance to wind erosion. By contrast, the resistance of the sandstone-gypsum layer to wind erosion was moderate, and that of the sandstone layer was weak. The experiments used to improve the aeolian foundation in this study can be applied to similar desert areas on the Arabian Peninsula and in North Africa.

\section{Notation}

$C_{\mathrm{c}} \quad$ curvature coefficient

$C_{\mathrm{u}} \quad$ uniformity coefficient

$m_{\mathrm{w}} \quad$ water added to the backfill material for rolling

$V \quad$ volume of backfill material

$w \quad$ moisture content of backfill material

$w_{\text {opt }} \quad$ optimum moisture content

$\lambda_{\mathrm{c}} \quad$ compaction coefficient of backfill material

$\rho \quad$ density of backfill

$\rho_{\mathrm{d}} \quad$ dry density of backfill

$\rho_{\mathrm{dmax}}$ maximum dry density of backfill material

\section{Introduction}

Desert areas occupy approximately one-third of the total land area of the Arabian Peninsula (Edgell, 2006). With vast resources of petroleum and solar energy, many construction projects are currently underway in the deserts (Olmstead and Tessler, 2008). Aeolian sands are the richest materials in desert areas (Elipe and López-Querol, 2014). However, the allowable bearing pressure of these soils is low, ranging from 49 to $118 \mathrm{kPa}$ (Abu Seif et al., 2016; Al-Sanad et al., 1993; Al-Taie et al., 2013; Padmakumar et al., 2012), which is considered poor for construction practices. One of the solutions to the problem is to improve the geotechnical properties of aeolian sand so that these soils with poor bearing capacity can also be used in construction. Geotechnical properties can be improved by procedures that increase the shear strength, decrease compressibility or otherwise render the physical properties of soil more suitable for projected engineering uses. Many studies have been conducted on improving the geotechnical properties of aeolian sand in desert areas of the world (Aiban, 1994; Albusoda and Salem, 2012; Stipho, 1984; Tiwari et al., 2016). These studies show that cementation results in a slight increase in friction and cohesion intercept and that residual strength parameters are the same for cemented and uncemented sands (Ismael et al., 1986). Among the principal cementing agents are gypseous soil, lime-silica fume, plastic waste strips and silica fume, among others (Albusoda and Hussein, 2013; Fattah et al., 2016; Kumar et al., 2016; Rahman and Ahmed, 2017).

Cemented aeolian sands possess distinctive geotechnical properties that are different from other soils, and they are used in construction associated with the oil industry, railways, highways and solar parks (Ismael et al., 1986). However, many cementations are expensive and also harmful to the environment and humans (Andavan and Kumar, 2020; Hall et al., 2012; Gholipoor Noroozi et al., 2015). Therefore, other economical and harmless sand stabilisers are needed.

This paper presents the results of an in situ compaction testing programme conducted to determine the geotechnical properties of backfill soils in the Mohammad bin Rashid Al Maktoum (MBR) Solar Park, the largest single-site solar energy project in the world, with a planned total production capacity of $5000 \mathrm{MW}$ by 2030. The site is in Saih Al Dahal $\left(24^{\circ} 42^{\prime} 19^{\prime \prime}\right.$ to $24^{\circ} 48^{\prime} 7^{\prime \prime} \mathrm{N}$, $55^{\circ} 17^{\prime} 57^{\prime \prime}$ to $\left.55^{\circ} 26^{\prime} 23^{\prime \prime} \mathrm{E}\right)$, Dubai, UAE, approximately $55 \mathrm{~km}$ south of Dubai City. The site is mainly covered with sand dunes and gravel plains. The most abundant building material in the 
project site is aeolian sand, which is non-cohesive, poorly graded fine sand with high permeability, low shear strength and low bearing capacity. The greatest problem faced by the project is how to use compaction treatment of aeolian sand as backfill soil and excavated sandstone and sabkha (gatch, gypsum) as sand fixation materials to achieve the requirements of various projects, including both sand fixation and bearing capacity. In this study, two sites were chosen to conduct compaction tests, in which moisture content, paving thickness, number of rolling passes, backfill layer deformation, compaction coefficient and California bearing ratio $(\mathrm{CBR})$ were measured.

\section{Study area}

The geology of the study area has been substantially influenced by the deposition of marine sediments associated with numerous sealevel changes during relatively recent geological time. The site is relatively low-lying with near-surface geology dominated by Quaternary- to Late Pleistocene-age mobile aeolian sands and sabkha/evaporate deposits. Alternating beds of calcarenite, carbonate sandstone, sands and cemented sands are under superficial deposits.

The site is in the hot, arid climate of Dubai, and in such climates, evaporation exceeds precipitation (rain, snow and dewfall). This climate regime produces characteristic hot desert terrains. Average

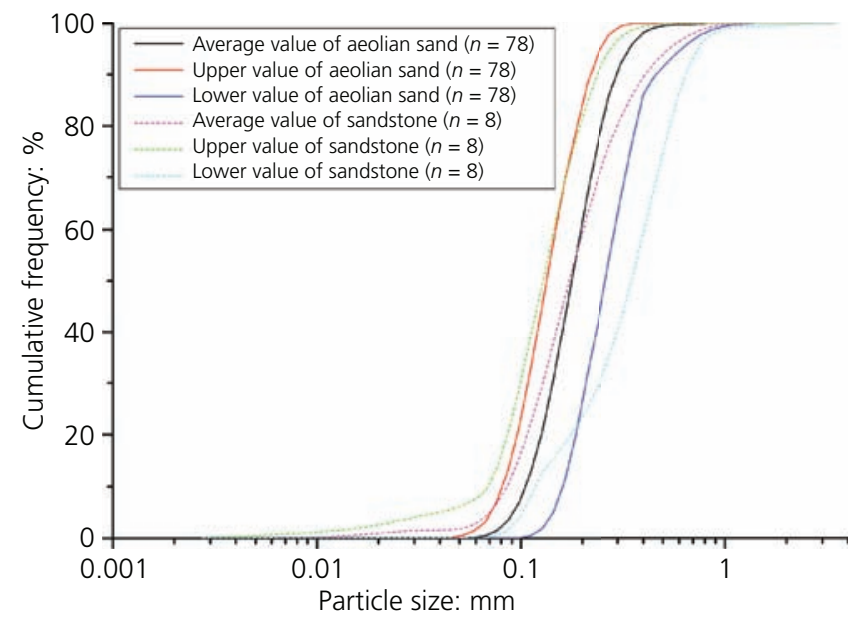

Figure 1. Grain size distribution curves of aeolian sands and sandstones in the project site. The 78 aeolian sand samples were collected at the top of dune ridges, and the eight sandstone samples were obtained from exploration pits annual rainfall may be only a few centimetres (even only a few millimetres in some parts), which usually occurs seasonally and sometimes only from a single cloudburst. Summer shade temperatures frequently exceed $40^{\circ} \mathrm{C}$, and humidity may approach $100 \%$ near the coast. The contrast between maximum night and day temperatures and between night and day humidity is often great. Strong, persistent winds are normal in many areas. In this unfavourable climate, concrete structures are adversely affected by the conditions, including high and large seasonal changes in temperature, high and large changes in relative humidity, strong desiccating winds, nighttime condensation, windborne salt-laden dust and high solar radiation.

\section{Aeolian sand}

After being blown and sorted by the wind over long periods, aeolian sand is non-plastic and uniformly graded fine sand (ASTM, 2017a). The particles move freely relative to one another, which explains their low mechanical properties. The particles were primarily in the size range of 0.05 to $0.5 \mathrm{~mm}$ (Figure 1), which accounted for $99.47 \%$ of the total. Within this range, the average content of very fine sand $(0.05-0.1 \mathrm{~mm})$ was $7.85 \%$, that of fine sand $(0.1-0.25 \mathrm{~mm})$ was $72.37 \%$ and that of medium sand $(0.25-0.5 \mathrm{~mm})$ was $19.25 \%$. The contents of silt, coarse sand and very coarse sand were very low, and there was no clay. The uniformity coefficient $C_{\mathrm{u}}$ was 1.867 , and the curvature coefficient $C_{\mathrm{c}}$ was 0.994 (ASTM, 2017a). Therefore, loose structure, poor grading, large porosity and low strength characterised the aeolian sand at the site, indicating that it was not suitable for use in engineering projects.

According to X-ray fluorescence spectrometer results (MLA650, FEI Co), the most abundant chemical component of aeolian sand in the site was calcium oxide, accounting for $33.94 \%$, followed by silicon dioxide, accounting for $29.23 \%$. The other chemical components, including aluminium oxide, ferric oxide, magnesium oxide, sodium oxide and potassium oxide, had small contributions to the total (Table 1). Compared with aeolian sand in China (Niu et al., 2019), the calcium oxide content of aeolian sand in the site was four to six times higher, whereas the silicon dioxide content was only half of that in China. The minerals in the aeolian sand at the site were primarily calcite, quartz, feldspar and calcium carbonate aggregate. The calcium carbonate content of the aeolian sand was between 60 and 90\% (Figure 2).

According to the Matcon Testing Laboratory (2018), the cohesion of aeolian sand in the site was zero, and the angle of shear resistance was from $30.0^{\circ}$ to $34.4^{\circ}$, with an average of $32.9^{\circ} \pm$

Table 1. Chemical composition (\%) of aeolian sand, gatch and sandstone in the project site in the United Arab Emirates (UAE) and of aeolian sand in China

$\begin{array}{llcccccccc}\text { Country } & \text { Sample } & \begin{array}{c}\text { Silicon } \\ \text { dioxide }\end{array} & \begin{array}{c}\text { Aluminium } \\ \text { oxide }\end{array} & \begin{array}{c}\text { Ferric } \\ \text { oxide }\end{array} & \begin{array}{c}\text { Magnesium } \\ \text { oxide }\end{array} & \begin{array}{c}\text { Calcium } \\ \text { oxide }\end{array} & \begin{array}{c}\text { Sodium } \\ \text { oxide }\end{array} & \begin{array}{c}\text { Potassium } \\ \text { oxide }\end{array} & \begin{array}{c}\text { Others } \\ \text { UAE }\end{array} \\ \text { Aeolian sand } & 29.23 & 2.51 & 0.97 & 1.41 & 33.94 & 1.00 & 0.61 & 29.95 \\ \text { UAE } & \text { Gatch } & 24.55 & 2.39 & 0.81 & 1.24 & 39.10 & 0.86 & 0.60 & 30.05 \\ \text { UAE } & \text { Sandstone } & 53.84 & 2.94 & 1.00 & 1.17 & 17.07 & 0.90 & 0.83 & 21.80 \\ \text { China } & \text { Aeolian sand } & 64.69 & 8.20 & 3.48 & 1.99 & 6.67 & 2.48 & 1.55 & 10.33\end{array}$




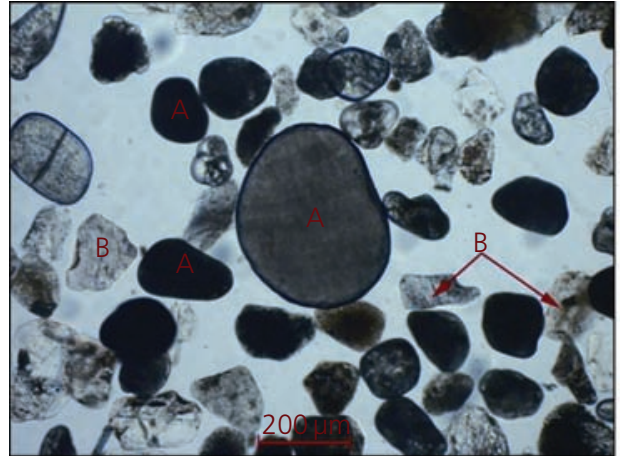

(a)

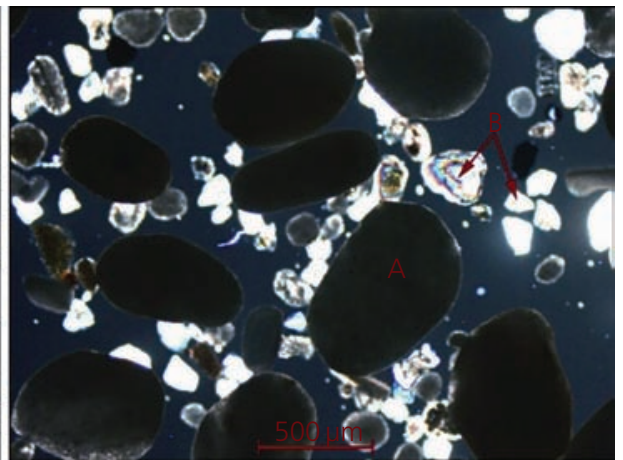

(b)

Figure 2. Polarising micrographs of aeolian sand particles in the project site (100x). (a) Image under plane-polarized light. (b) Image under cross-polarized light. In the images, A indicates rounded or elliptical microcrystalline carbonate aggregate, and B indicates quartz or feldspar clastic mineral

$1.6^{\circ}$ (mean \pm standard deviation, $n=19$ ). The angle of shear resistance is lower than that in aeolian sand in the centre of the Taklimakan Desert $\left(31.9^{\circ}-36.3^{\circ}\right.$; Yao et al., 2001) and in the $\mathrm{Mu}$ Us Desert $\left(33^{\circ}-48^{\circ}\right.$; Zhang et al., 2015) in China but is higher than that in the Thar Desert $\left(27.1^{\circ}-32.0^{\circ}\right)$ in India (Prasad and Purohit, 2017). The value is equivalent to the internal friction angle of aeolian sand in the Baiji region of Iraq and Kuwait (AlSanad et al., 1993; Fattah et al., 2016).

Compaction characteristics of the soils were determined by using standard Proctor's test according to the procedure in ASTM D 698-12e2 (ASTM, 2012). The maximum dry density (MDD) varied from 1.68 to $1.70 \mathrm{~g} / \mathrm{cm}^{3}$ at the optimum moisture content (OMC) from 15.7 to $16.5 \%$. The mean value of MDD was $1.69 \mathrm{~g} / \mathrm{cm}^{3}$, and that of $\mathrm{OMC}$ was $16.2 \%$. Compared with the $\mathrm{Mu}$ Us Desert (Ren et al., 2018), the Horqin Desert (Zhang et al., 2013), India's Thar Desert (Tiwari et al., 2016), Algeria's Valgra Desert (Cherrak et al., 2015) and Saudi Arabia (Rahman and Ahmed, 2017), the MDD was lower and the OMC was higher at the site in the UAE.

\section{Sand fixation materials}

According to geological exploration data (Matcon Testing Laboratory, 2018), the underlying stratum of loose Quaternary sediments in the project area was brownish-red sandstone, with clear horizontal or oblique bedding, calcareous cementing and highly weathering. Under the sandstone was white or greyishwhite sabkha, which was primarily porous sand debris or silty limestone (locally known as gatch) and gypsum sediments, containing the remains of marine microorganisms.

Sandstone, sandstone-gatch (sandstone mixed with gatch) and sandstone-gypsum (sandstone mixed with gypsum) were used as sand fixation materials to cover the surface layer, and aeolian sand was used as backfill material. Therefore, three samples of those four materials were collected to run geotechnical engineering property tests. The tests included grain size, natural moisture content, specific gravity, standard Proctor's test and a soluble salt test. The test results are shown in Tables 2 and 3.

The aeolian sand had low contents of chloride and sulfate (Table 3) and therefore no corrosiveness to building materials. The sandstone and sandstone-gypsum had high sulfate contents, 2.15 and $1.99 \mathrm{~g} / \mathrm{l}$, respectively, which are corrosive to concrete. However, when used as a sand fixation material, it is on the surface of the site in a relatively thin layer, so the corrosiveness to concrete can be ignored.

\section{Foundation treatment method}

Technical requirements for backfilling

According to the owner's technical specification (OTS), the technical requirements for the foundation can be classified into three working conditions.

- Condition I. Backfill materials of road or load area should reach the compaction coefficient of $98 \%$ (the MDD and OMC should be measured by the modified effort Proctor's test according to ASTM D 1557-12e1 (ASTM, 2003), with a hammer weight of $4.5 \mathrm{~kg}$ and a drop distance of $45.7 \mathrm{~mm}$ ).

- Condition II. Backfill materials of the ditch under the road should reach the compaction coefficient of $95 \%$.

- Condition III. Backfill materials in other sites (such as embankment and non-load area, among others) should reach the compaction coefficient of $90 \%$.

\section{Backfilling and rolling equipment}

According to the backfill technical requirements and relevant engineering experience, a Dynapac SD-200 vibratory roller was selected for rolling. The roller weight was $20 \mathrm{t}$, and the speed was 2 to $5 \mathrm{~km} / \mathrm{h}$. The vibration frequency was 0 to $30.8 \mathrm{~Hz}$, and the amplitude was 0.9 to $1.8 \mathrm{~mm}$. To backfill the site, a loader was used, and to water the site, two water trucks (5000 and 10000 gallons; 1 gallon $=4.5$ litres) were used. 
Table 2. Geotechnical characteristics of the backfill and sand fixation materials

\begin{tabular}{|c|c|c|c|c|c|c|}
\hline Backfill materials & & $\begin{array}{c}\text { Fine grain } \\
(d \leq 0.075 \mathrm{~mm}): \%\end{array}$ & $\begin{array}{l}\text { Moisture } \\
\text { content: \% }\end{array}$ & $\begin{array}{l}\text { Specific } \\
\text { gravity }\end{array}$ & $\begin{array}{l}\text { Maximum dry } \\
\text { density: } \mathrm{g} / \mathrm{cm}^{3}\end{array}$ & $\begin{array}{l}\text { Optimum moisture } \\
\text { content: } \%\end{array}$ \\
\hline Aeolian sand & Sample 1 & 1.0 & 0.1 & 2.65 & 1.69 & 16.5 \\
\hline Aeolian sand & Sample 2 & 3.0 & 0.6 & 2.65 & 1.68 & 15.9 \\
\hline Aeolian sand & Sample 3 & 4.0 & 0.9 & 2.65 & 1.70 & 16.2 \\
\hline Aeolian sand & Max & 4.0 & 0.9 & 2.65 & 1.70 & 16.5 \\
\hline Aeolian sand & Min & 1.0 & 0.1 & 2.65 & 1.68 & 15.7 \\
\hline Aeolian sand & Mean & 2.7 & 0.5 & 2.65 & 1.69 & 16.2 \\
\hline Sandstone & Sample 1 & 5.0 & 0.7 & 2.66 & 1.79 & 14.3 \\
\hline Sandstone & Sample 2 & 5.0 & 0.6 & 2.66 & 1.76 & 15.2 \\
\hline Sandstone & Sample 3 & 4.0 & 0.8 & 2.65 & 1.77 & 15.0 \\
\hline Sandstone & $\operatorname{Max}$ & 5.0 & 0.8 & 2.66 & 1.79 & 15.2 \\
\hline Sandstone & Min & 4.0 & 0.6 & 2.65 & 1.76 & 14.3 \\
\hline Sandstone & Mean & 4.7 & 0.7 & 2.66 & 1.77 & 14.8 \\
\hline Sandstone-gatch & Sample 1 & 16.0 & 0.9 & 2.65 & 1.76 & 12.9 \\
\hline Sandstone-gatch & Sample 2 & 7.0 & 3.3 & 2.66 & 1.74 & 16.4 \\
\hline Sandstone-gatch & Sample 3 & 14.0 & 2.4 & 2.66 & 1.75 & 16.0 \\
\hline Sandstone-gatch & Max & 16.0 & 3.3 & 2.66 & 1.76 & 16.4 \\
\hline Sandstone-gatch & Min & 7.0 & 0.9 & 2.65 & 1.74 & 12.4 \\
\hline Sandstone-gatch & Mean & 12.3 & 2.2 & 2.66 & 1.75 & 15.1 \\
\hline Sandstone-gypsum & Sample 1 & 7.0 & 1.6 & 2.65 & 1.73 & 16.8 \\
\hline Sandstone-gypsum & Sample 2 & 12.0 & 0.6 & 2.66 & 1.74 & 16.4 \\
\hline Sandstone-gypsum & Sample 3 & 29.0 & 0.6 & 2.63 & 1.74 & 16.4 \\
\hline Sandstone-gypsum & Max & 29.0 & 1.6 & 2.65 & 1.74 & 16.8 \\
\hline Sandstone-gypsum & Min & 7.0 & 0.6 & 2.63 & 1.73 & 16.4 \\
\hline Sandstone-gypsum & Mean & 16.0 & 0.9 & 2.65 & 1.74 & 16.5 \\
\hline
\end{tabular}

Table 3. Contents of soluble salts and pH of the backfill and sand fixation materials

\begin{tabular}{|lccc|} 
Materials & $\begin{array}{c}\text { Chloride ion } \\
\text { content: \% }\end{array}$ & $\begin{array}{c}\text { Sulfate } \\
\text { content: } \mathbf{g} / \mathbf{l}\end{array}$ & $\mathbf{p H}$ \\
\hline Aeolian sand & $<0.01$ & 0.07 & 7.8 \\
Sandstone & 0.02 & 2.15 & 7.4 \\
Sandstone-gatch & $<0.01$ & 0.13 & 7.5 \\
Sandstone-gypsum & 0.01 & 1.99 & 7.5 \\
\hline
\end{tabular}

\section{Backfilling and rolling technology \\ Lift thickness of backfill}

According to the recommended standard for rolling in China's 'Guidelines for highway design and construction in sandy desert area', the average thickness of each layer of aeolian sand is 30 to $50 \mathrm{~cm}$ (Ministry of Transport of the People's Republic of China, 2008). On this basis, the thickness of the aeolian sand lift in the test was 30 or $50 \mathrm{~cm}$.

\section{Watering of backfill soil}

According to exploratory data, the natural moisture content of the aeolian sand varied from 0.1 to $0.9 \%$ because of different burial depths. However, owing to the high temperatures and dry and windy conditions, the moisture in the backfill material evaporated easily, and the content decreased significantly to a low level during excavation, transportation and stacking. Therefore, the moisture content of the backfill was considered to be $0 \%$, and the amount of water added to the backfill material was obtained according to the following formula:
1. $m_{\mathrm{w}}=w_{\mathrm{opt}} \cdot \rho \cdot V$

where $m_{w}$ is the water added to the backfill material for rolling; $w_{\text {opt }}$ is the OMC; $\rho$ is the density of backfill material before watering; and $V$ is the volume of backfill material.

Two sites were designed for the backfill rolling test, and each site was divided into four blocks according to the thickness of the backfill layer, the thickness of the sand fixation material and moisture content (Table 4 and Figure 3). Each block was approximately $6 \times 20 \mathrm{~m}$.

\section{Backfill and rolling process}

Backfilling and rolling processes for aeolian sand and sand fixation materials were summarised in a flow chart (Figure 4). The number of rolling passes was adjusted according to the dry density and compaction coefficient test results.

\section{Test results}

According to the requirements of the rolling test program, the moisture content, lift thickness, compaction coefficient and CBR of backfill material were monitored during the rolling process.

\section{Change in moisture content}

To achieve better compaction, the backfill soil and sand fixation materials should be watered before rolling (Rogers et al., 1994). To meet the requirements of the backfill and the rolling test, the moisture content of backfill and sand fixation materials was controlled within 
Table 4. Backfill rolling test blocks and working condition combinations

\begin{tabular}{|c|c|c|c|c|c|}
\hline Test site & & Backfill material & Lift thickness $(\mathrm{cm}) \times$ layers & Rolling passes & Controlled moisture content: \% \\
\hline I & A & Aeolian sand & $30 \times 1$ & $2,4,6,8,10$ & Not watered \\
\hline । & B & Aeolian sand & $30 \times 3$ & $2,4,6,8,10$ & $w_{\mathrm{opt}}+5$ \\
\hline । & B & Sandstone-gypsum & $15 \times 1$ & $2,4,6,8,10$ & $w_{\text {opt }}+5$ \\
\hline । & C & Aeolian sand & $30 \times 3$ & $2,4,6,8,10$ & $w_{\mathrm{opt}}+5$ \\
\hline । & C & Sandstone-gatch & $15 \times 1$ & $2,4,6,8,10$ & $w_{\text {opt }}+5$ \\
\hline । & D & Aeolian sand & $30 \times 3$ & $2,4,6,8,10$ & $w_{\mathrm{opt}}+5$ \\
\hline । & D & Sandstone & $15 \times 1$ & $2,4,6,8,10$ & $w_{\mathrm{opt}}+5$ \\
\hline$\|$ & A & Aeolian sand & $50 \times 1$ & $4,6,8,10,12$ & Not watered \\
\hline ॥ & B & Aeolian sand & $50 \times 3$ & $4,6,8,10,12$ & $w_{o p t}+5$ \\
\hline$\|$ & B & Sandstone-gypsum & $30 \times 1$ & $4,6,8,10,12$ & $w_{\mathrm{opt}}+5$ \\
\hline$\|$ & C & Aeolian sand & $50 \times 3$ & $4,6,8,10,12$ & $w_{\mathrm{opt}}+5$ \\
\hline ॥ & C & Sandstone-gatch & $30 \times 1$ & $4,6,8,10,12$ & $w_{\mathrm{opt}}+5$ \\
\hline$\|$ & D & Aeolian sand & $50 \times 3$ & $4,6,8,10,12$ & $w_{\mathrm{opt}}+5$ \\
\hline$\|$ & D & Sandstone & $30 \times 1$ & $4,6,8,10,12$ & $w_{\mathrm{opt}}+5$ \\
\hline
\end{tabular}

Plane layout of test sites I and II
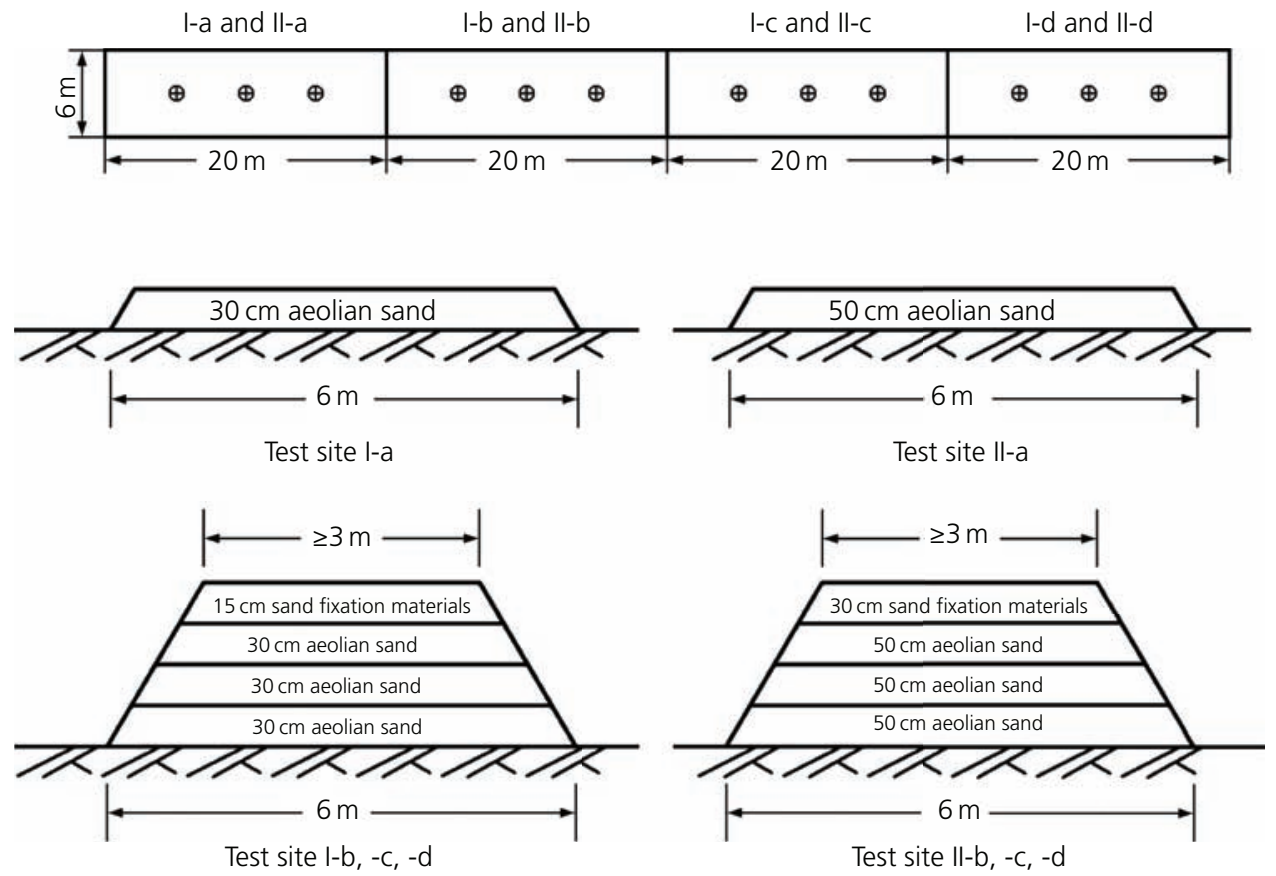

Figure 3. Plane layout and profile layouts of the two sites used for backfill rolling tests. Note: (a) the thickness of the backfill is loose laying depth; $(b) \oplus$ is the top elevation measurement spot

the range of $\mathrm{OMC}+5 \%$ (Figures 5 and 6 ). With the increase in the number of rolling passes, the moisture content of the backfill gradually decreased. In cohesionless materials such as aeolian sand, water plays a lubricating role between soil particles during the compaction process, which is more conducive to rearrangement and compaction of soil particles in vibration rolling (Munkholm and Kay, 2002). Because the project site was in a tropical desert area, the water evaporated easily. Therefore, the moisture content was controlled at the limit of $\mathrm{OMC}+5 \%$ when watering. Backfilling and rolling performed better at this level, and supplemental watering during the rolling process was reduced or avoided. However, because moisture was lost during loading, transporting and unloading, the initial moisture content did not reach $\mathrm{OMC}+5 \%$.

\section{Backfill layer deformation}

During the rolling process, with the increase in the number of rolling passes, the deformation settlement of backfill materials increased continuously. The deformation process of the backfill material layer is shown in Figure 7.

There was a considerable decrease in the thickness of the dry aeolian sand layer with the increase in the number of rolling 
Treatments to improve the aeolian sand foundation in solar park construction

Xie, Zhu, Xiao et al.

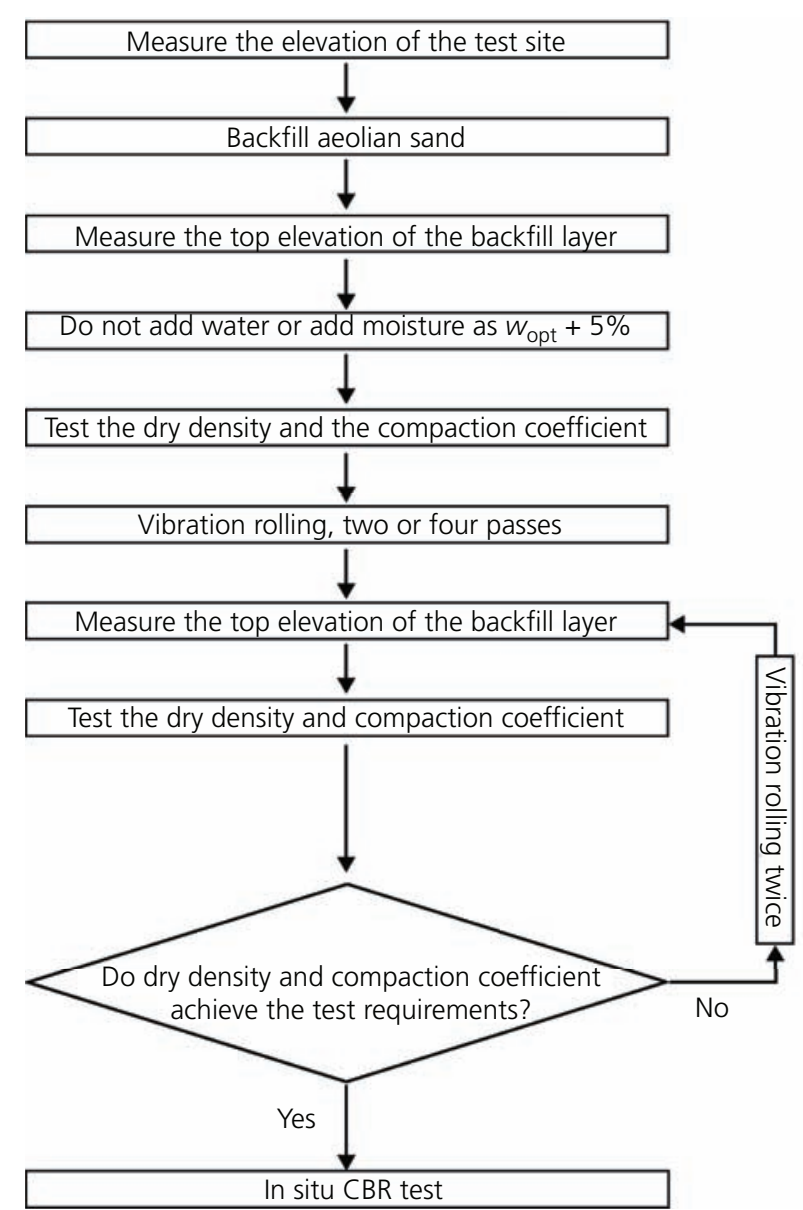

(a)

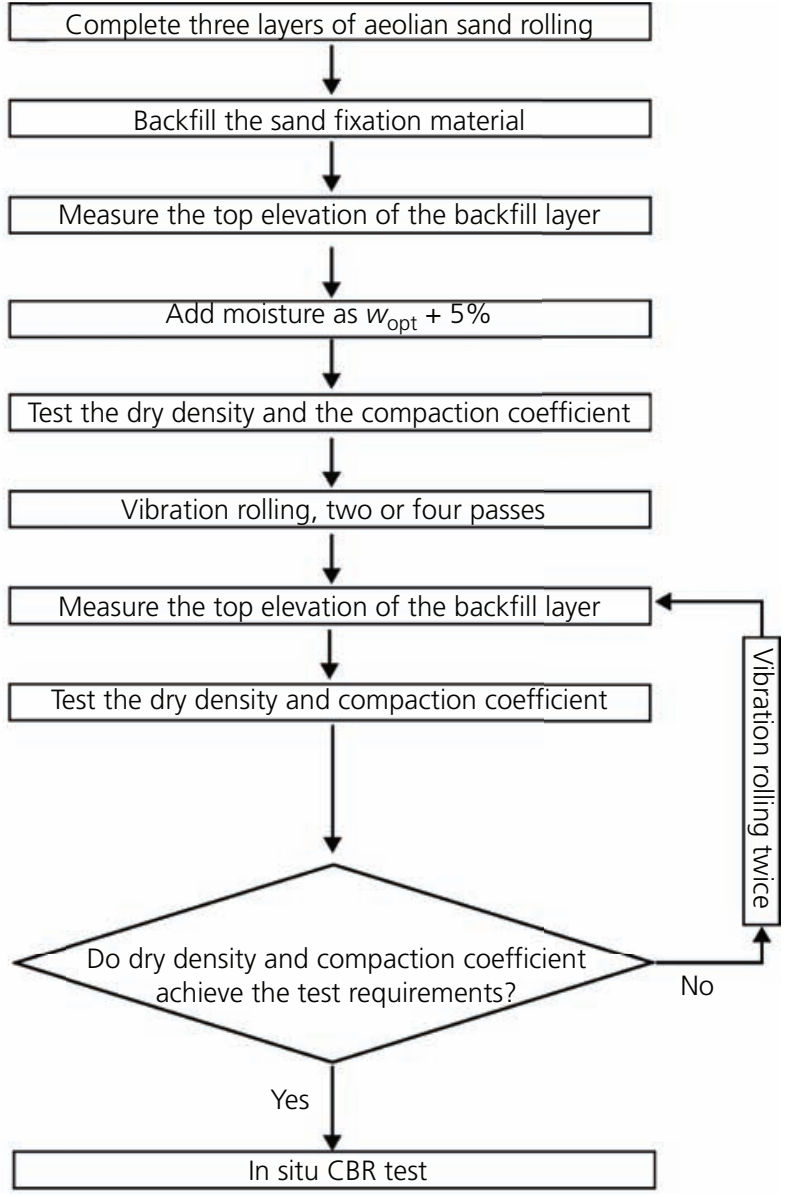

(b)

Figure 4. Flow chart of the backfill and rolling process. (a) Aeolian sand backfilling and rolling processes; (b) sand fixation material rolling processes

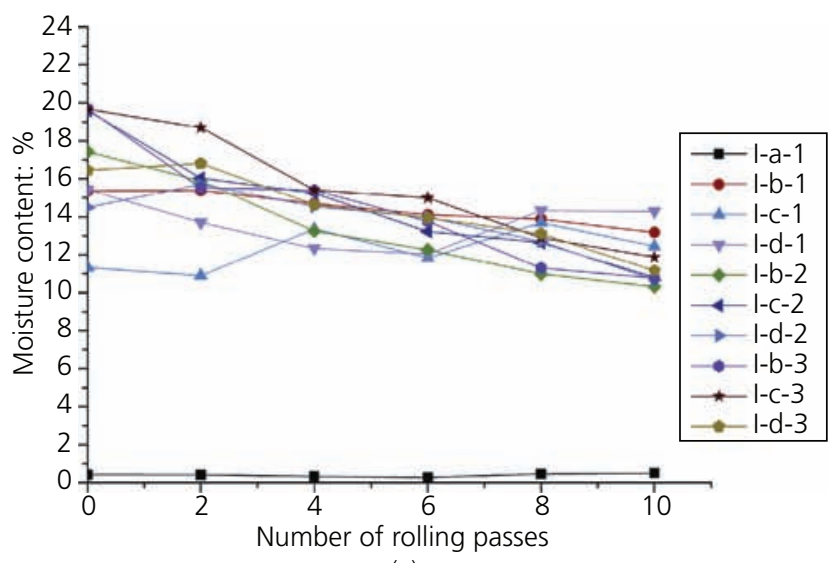

(a)

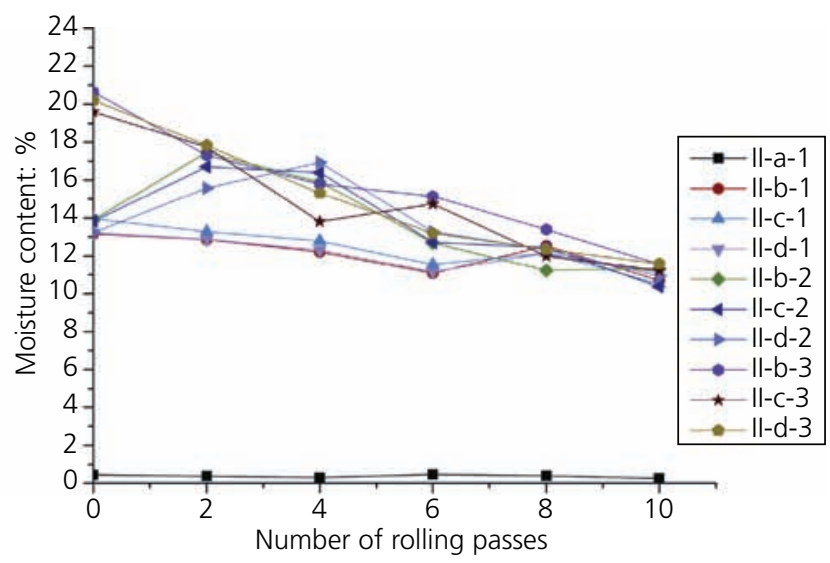

(b)

Figure 5. Changes in moisture content (\%) of aeolian sand during rolling. (a) Test site I (30 cm thickness); (b) test site II (50 cm thickness)

passes. The cumulative compression deformation of the $30 \mathrm{~cm}$ dry aeolian sand layer was $4.8 \%$ (I-a-1), and that of the $50 \mathrm{~cm}$ dry aeolian sand layer was $2.9 \%$ (II-a-1), indicating that dry aeolian sand was not easily compacted. When the $30 \mathrm{~cm}$ wet aeolian sand layer was rolled twice, the compression deformation increased rapidly by an average of $4.73 \%$. During the next rolling, the 


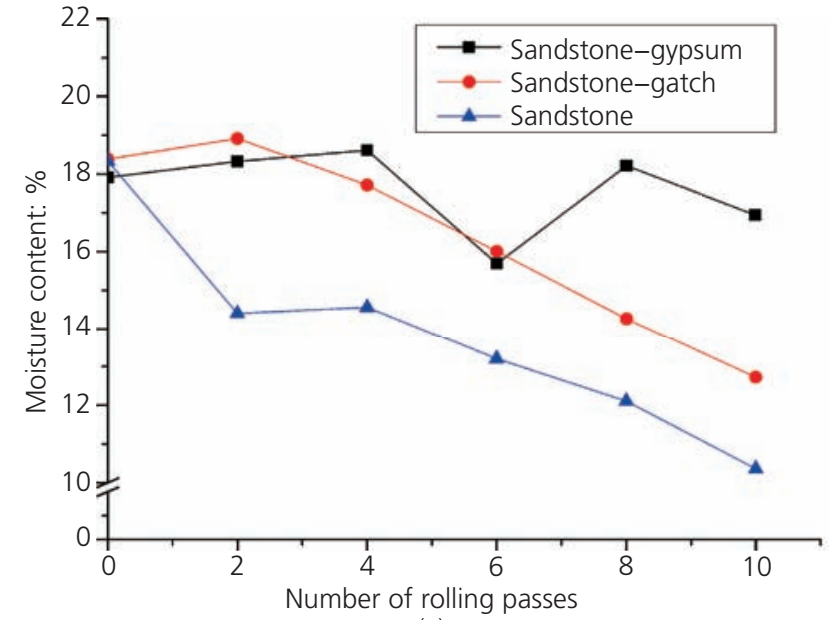

(a)

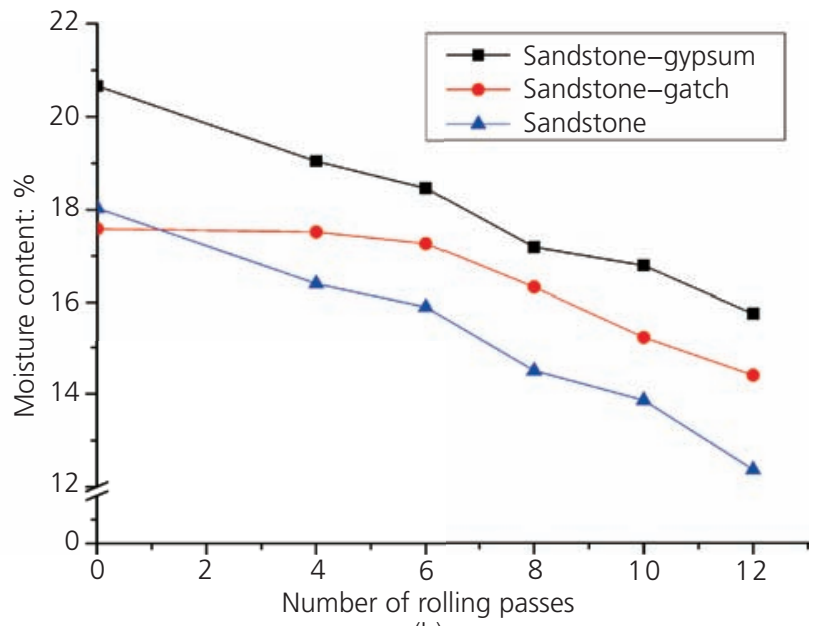

(b)

Figure 6 . Changes in moisture content (\%) of sand fixation materials during rolling. (a) Test site I (15 cm thickness); (b) test site II (30 cm thickness)

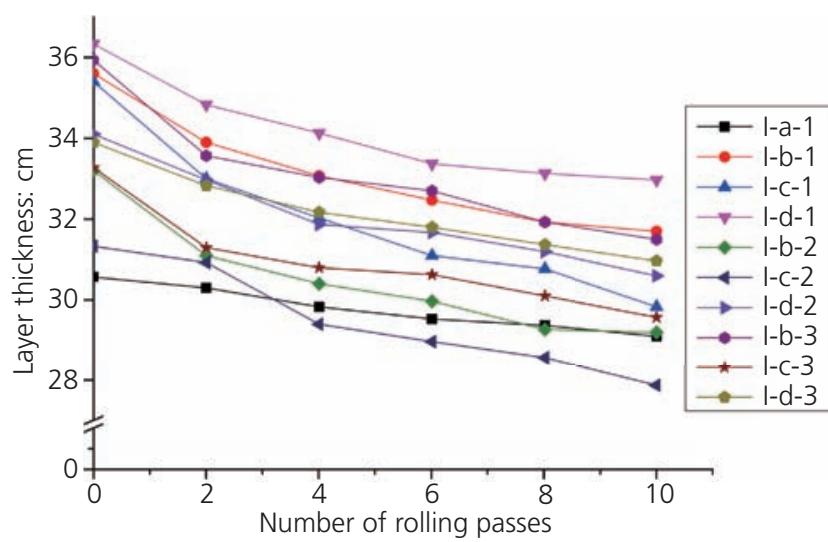

(a)

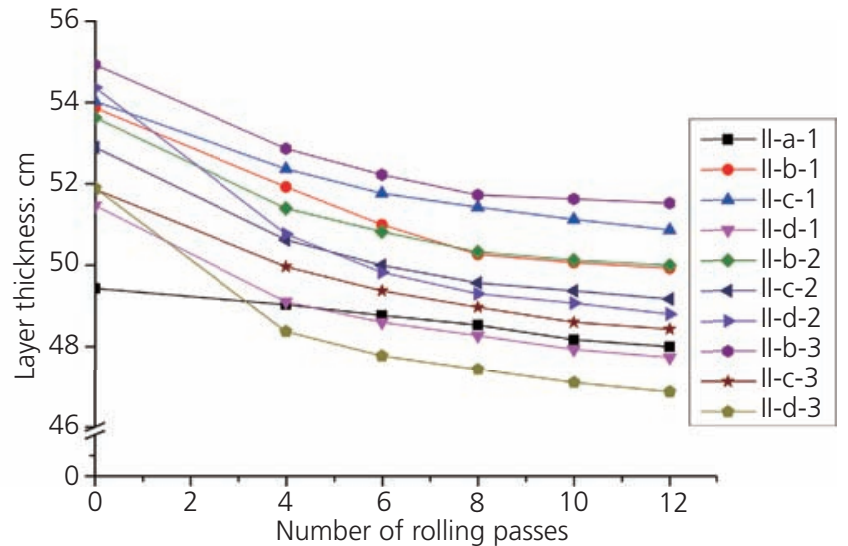

(b)

Figure 7. Deformation of the aeolian sand layers with the number of rolling passes. (a) Test site I ( $30 \mathrm{~cm}$ thickness); (b) test site II (50 cm thickness)

compression deformation increased slowly. With ten rolling passes, the cumulative compression deformation was $8.65 \%$ to $15.73 \%$, with an average of $11.28 \%$. In the first several rolling passes, the compression deformation of the $50 \mathrm{~cm}$ wet aeolian sand layer increased rapidly. With four rolling passes, the average compression deformation reached $4.50 \%$. However, deformation increased very little with additional rolling passes. With 12 rolling passes, the cumulative compression deformation was $5.86 \%$ to $10.24 \%$, with an average of $7.44 \%$.

With the increase in the number of rolling passes, the thickness of sand fixation layers gradually decreased (Figure 8). The average compression deformation of the sandstone-gypsum layer was $14.33 \%$, that of the sandstone-gatch layer was $11.94 \%$ and that of the sandstone layer was $17.21 \%$, which were values positively related to the compressive strength of the three sand fixation materials.

\section{Variation in compaction coefficient}

The sand filling method and a nuclear density hygrometer (Seaman Nuclear Corporation) were used to measure the density of backfill material (ASTM, 2017b). Using the density and moisture contents measured by the above methods, the dry density and compaction coefficient of the backfill material were calculated using the following formulas:

2. $\rho_{\mathrm{d}}=\frac{\rho}{1+0.01 w}$

3. $\lambda_{\mathrm{c}}=\frac{\rho_{\mathrm{d}}}{\rho_{\mathrm{dmax}}}$ 


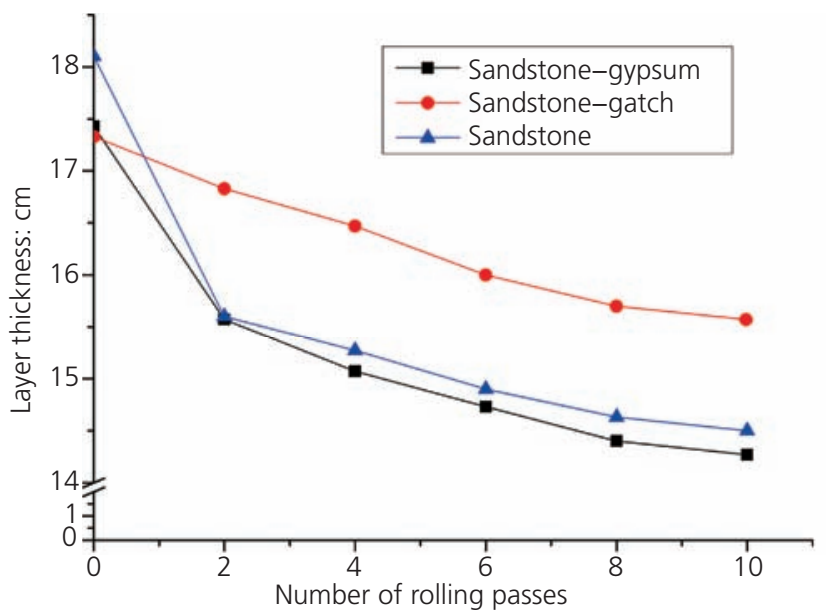

(a)

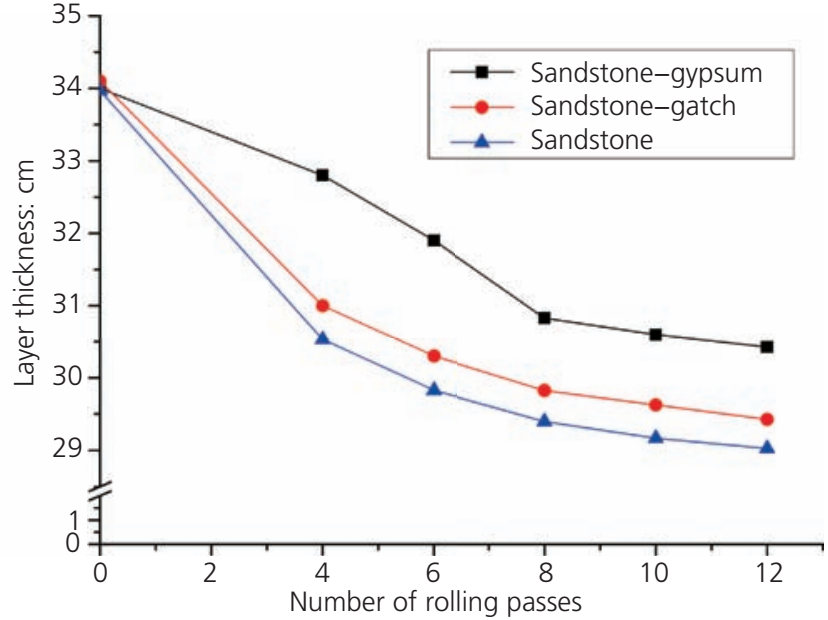

(b)

Figure 8. Deformation of the sand fixation material layers with the number of rolling passes. (a) Test site I (15 cm thickness); (b) test site II (30 $\mathrm{cm}$ thickness)

where $\rho_{\mathrm{d}}$ is the dry density of backfill $\left(\mathrm{kg} / \mathrm{m}^{3}\right) ; \rho$ is the density of backfill $\left(\mathrm{kg} / \mathrm{m}^{3}\right) ; w$ is the moisture content of backfill material $(\%) ; \lambda_{\mathrm{c}}$ is the compaction coefficient of backfill material; and $\rho_{\text {dmax }}$ is the MDD of backfill material $\left(\mathrm{kg} / \mathrm{m}^{3}\right)$.

Figure 9 shows the changes in the compaction coefficient of aeolian sand during rolling. The compaction coefficient of the dry sand layer increased slowly with the increase in the number of rolling passes but remained lower than that of the wet sand layers. When the $30 \mathrm{~cm}$ dry sand layer was rolled ten times, the compaction coefficient reached 0.90 . When the $50 \mathrm{~cm}$ dry sand layer was rolled 12 times, the compaction coefficient also reached 0.90 . Therefore, the dry sand could not be easily compacted. The field vibration rolling test showed that the dry density at $0 \%$ moisture content was less than that at the OMC. Hence, the vibration rolling method of dry sand is not suitable for the project.

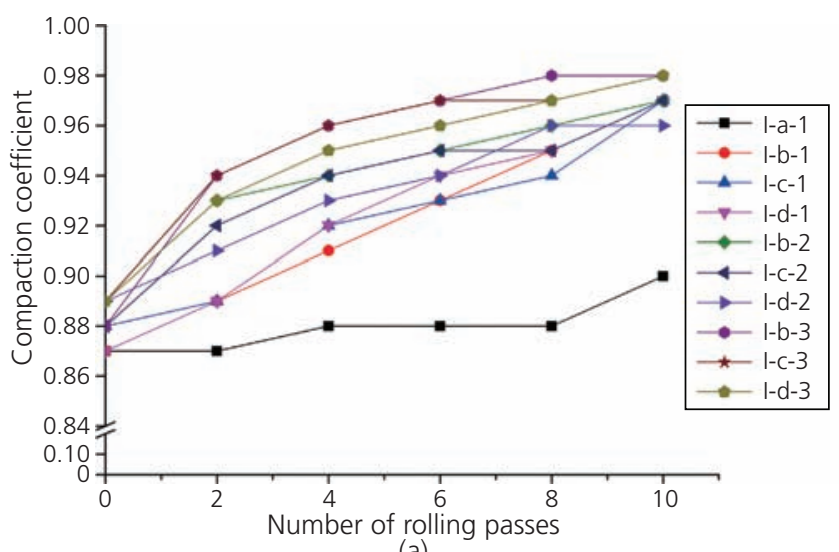

(a)
Wet sand is more easily compacted than dry sand. When the $30 \mathrm{~cm}$ wet sand layer was rolled twice, the compaction coefficient was 0.89 to 0.94 , with a mean of 0.92 , which is close to or exceeds the OTS' requirement of 0.90 . When the $30 \mathrm{~cm}$ wet sand layer was rolled ten times, the compaction coefficient was 0.96 to 0.98 , with a mean of 0.97 , which is close to or meets the OTS' requirement of 0.98 .

When the $50 \mathrm{~cm}$ wet sand layer was rolled four times, the compaction coefficient was 0.90 to 0.95 , with a mean of 0.92 , which reaches or exceeds the requirement of 0.90 . After 12 rolling passes, the compaction coefficient of the $50 \mathrm{~cm}$ wet sand layer was 0.96 to 0.99 , with a mean of 0.97 , which is close to or meets the requirement of 0.98 .

The compaction coefficient of dry sand increased only after watering (without rolling), especially in the $50 \mathrm{~cm}$ thick aeolian

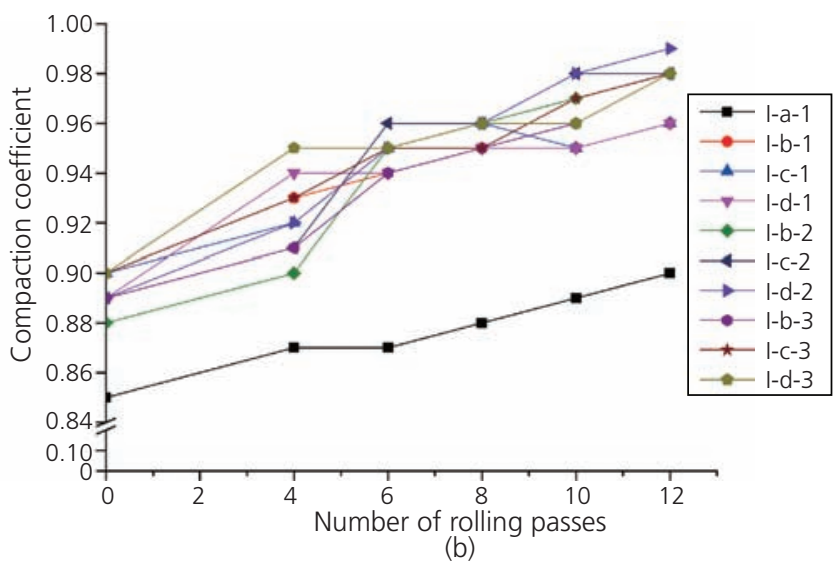

(b)

Figure 9. Changes in the compaction coefficient of aeolian sand layers with the number of rolling passes. (a) Test site I ( $30 \mathrm{~cm}$ thickness); (b) test site II (50 cm thickness) 
Geotechnical Research

Volume 7 issue 4
Treatments to improve the aeolian sand

foundation in solar park construction

Xie, Zhu, Xiao et al. sand, and the compaction coefficient of some test sections reached 0.90 . This result was related to the addition of water. In this test, large amounts of water were sprinkled on the top of the $50 \mathrm{~cm}$ dry sand layer, with the water penetrating freely, which is equivalent to the hydro-compaction method (Munro, 2017). The aeolian sand in the top layer was more likely to reach the compaction coefficient of 0.90 in a short time, which indirectly showed that water played an important role in backfill compaction.

Figure 10 shows the changes in the compaction coefficient of sand fixation materials during rolling. In the initial stage of rolling, the compaction coefficient of the three materials in a $15 \mathrm{~cm}$ thickness increased rapidly with the increase in the number of rolling passes. After six rolling passes, the compaction coefficient could exceed 0.92 . In the later stage of rolling, the coefficient of compaction increased slowly. When rolled ten times, the coefficient of compaction reached or exceeded 0.97 . However, the compaction coefficient of the three materials in a $30 \mathrm{~cm}$ thickness increased slowly with the increase in the number of rolling passes in the initial stage of rolling. When rolled ten times, the compaction coefficient reached 0.92. After 12 rolling passes, the compaction coefficient increased rapidly and reached or exceeded 0.97 .

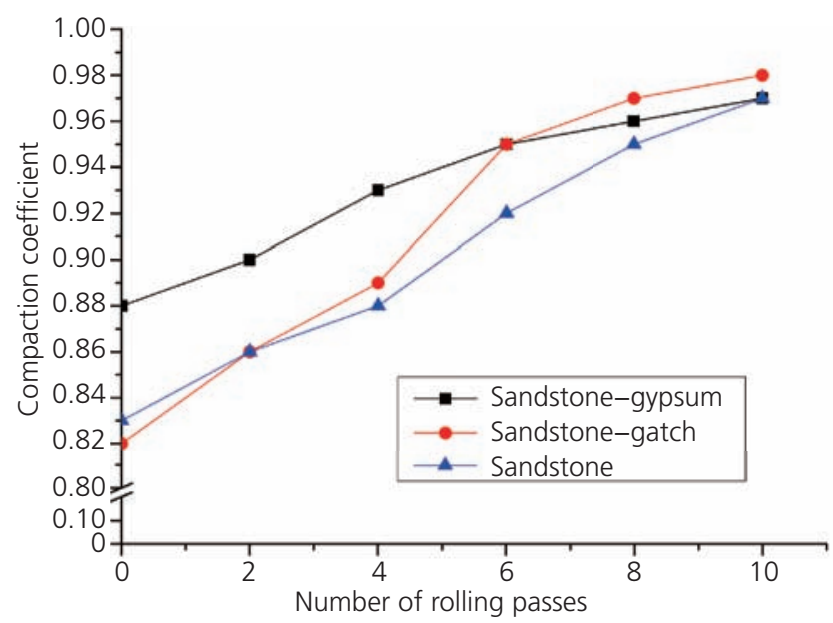

(a)
When the three materials in a $15 \mathrm{~cm}$ lift thickness were rolled ten times, the compaction coefficient met the engineering requirements. However, the three materials in a $30 \mathrm{~cm} \mathrm{lift}$ thickness required 12 rolling passes in order for the compaction coefficient to meet the engineering requirements.

\section{CBR field tests}

The in situ CBR test results are summarised in Table 5 (ASTM, 2009).

The mean CBR values of compacted sandstone-gypsum in test area I ( $15 \mathrm{~cm}$ thickness) and test area II (30 cm thickness) were nearly equal, at $24.5 \%$ and $22.0 \%$, respectively, indicating that they both had high bearing capacity. However, the mean CBR values of compacted sandstone-gatch in test area I and test area II were different, at $30.0 \%$ and $23.0 \%$, respectively. In test area I, the CBR values of both sandstone-gypsum and sandstone-gatch were greater than those in test area II. Both sandstone and aeolian sand had smaller CBR values that ranged from $5 \%$ to $9 \%$, which were much lower than those of sandstone-gypsum and sandstone-gatch, indicating that both had low bearing capacity.

The CBR values were greater than $20 \%$ for sandstone-gypsum and sandstone-gatch, indicating their suitability for subgrade and

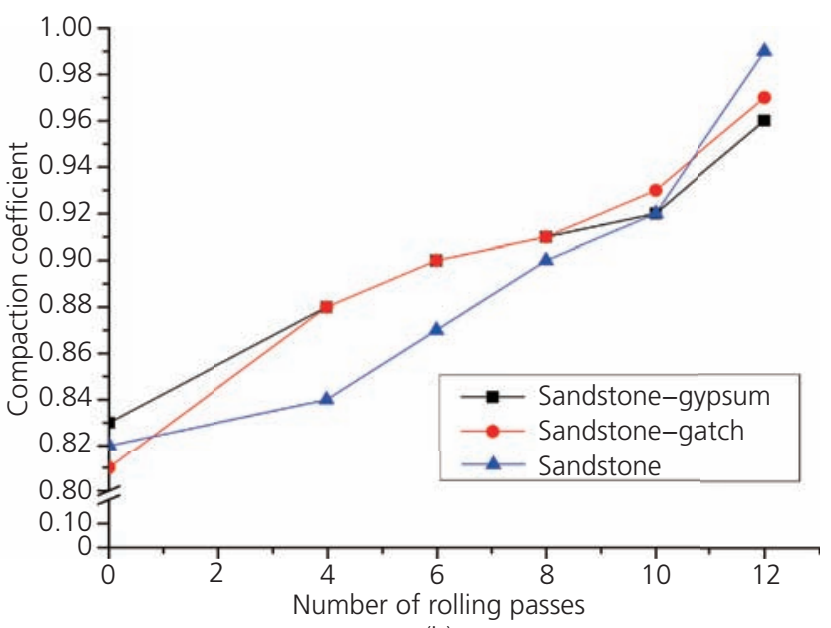

(b)

Figure 10. Changes in the compaction coefficient of sand fixation material layers with the number of rolling passes. (a) Test site I (15 cm thickness); (b) test site II (30 cm thickness)

Table 5. Summary of CBR field test results

\begin{tabular}{|c|c|c|c|c|c|c|}
\hline \multirow{3}{*}{ Backfill material } & \multicolumn{6}{|c|}{ Field CBR value: \% } \\
\hline & \multicolumn{3}{|c|}{ Test area I } & \multicolumn{3}{|c|}{ Test area II } \\
\hline & Max. & Min. & Mean & Max. & Min. & Mean \\
\hline Aeolian sand & 8.0 & 6.0 & 6.8 & 7.0 & 5.0 & 6.3 \\
\hline Sandstone-gypsum & 25.0 & 24.0 & 24.5 & 23.0 & 21.0 & 22.0 \\
\hline Sandstone-gatch & 34.0 & 26.0 & 30.0 & 24.0 & 22.0 & 23.0 \\
\hline Sandstone & 7.0 & 7.0 & 7.0 & 9.0 & 8.0 & 8.5 \\
\hline
\end{tabular}


pavement filling materials for various roads in the site. With CBR values of $7 \%$ to $9 \%$, the sandstone is suitable as sand fixation material and subgrade filling material in the heliostats area. With CBR values of $5 \%$ to $8 \%$, the aeolian sand is suitable as site backfilling material.

\section{Wind erosion resistance}

After completion of the backfill rolling test on 12 July 2018, iron bars with a sign ring were inserted into the surface layer of the sand fixation material to monitor the wind erosion depth. After almost half a year of observation, on 19 January 2019, the surface layer of the sandstone-gatch remained in good condition, and the wind erosion depth was zero, indicating strong resistance against wind erosion (Figure 11). Blown sand weakly eroded the surface of the sandstone-gypsum. The wind erosion depth was 2 to $3 \mathrm{~mm}$, and an uneven surface formed. These results indicated that the sandstonegypsum had moderate resistance against wind erosion. The surface of sandstone eroded approximately $13 \mathrm{~mm}$, forming a raised gravel surface and indicating weak resistance against wind erosion.

Wind erosion resistance tests were conducted on 20 January 2019. Each erosion plot was $1.5 \times 2 \mathrm{~m}$ and was enclosed by wood strips (Figure 12). The time of wind erosion was $10 \mathrm{~min}$, and the wind speed was 16 to $18 \mathrm{~m} / \mathrm{s}$, based on the highest wind speeds recorded at the local meteorological station. The wind was produced with an AJS-MH58 portable pneumatic extinguisher. The eroded materials were collected and weighed in the laboratory. The sandstone-gatch layer had a strong resistance to wind erosion, and the eroded weight of the surface layer was $4.57 \mathrm{~g} /\left(\mathrm{min} \cdot \mathrm{m}^{2}\right)$. The sandstone-gypsum layer had moderate resistance to wind erosion, and the eroded weight was $23.73 \mathrm{~g} /\left(\min \cdot \mathrm{m}^{2}\right)$. The sandstone layer had a weak resistance to wind erosion, and the eroded weight was $111.36 \mathrm{~g} /\left(\mathrm{min} \cdot \mathrm{m}^{2}\right)$. The results of the wind erosion tests were consistent with those of 6month monitoring of natural wind erosion.

\section{Conclusions}

The aeolian sand in the MBR Solar Park Phase IV project in Dubai was fine, loose, poor in grading, high in porosity, low in strength and high in fluidity and needed treatment to meet the requirements of various projects. With aeolian sand used as backfill material and with sandstone, gatch and gypsum excavated during site levelling used as sand fixation materials, rolling tests were conducted to monitor the changes in moisture content, backfill layer deformation, compaction coefficient and CBR. The test results showed the following.

- When dry aeolian sand in 30 and $50 \mathrm{~cm}$ lift thicknesses was vibration rolled, the compaction coefficient increased slowly, and the final compaction coefficient was close to or reached 0.90 . Thus, the dry aeolian sand was not easily compacted, and therefore, the dry sand vibration rolling method was not suitable for the project site.

- Rolling had a good effect on the wet sand. In a $30 \mathrm{~cm}$ lift thickness of wet sand, the compaction coefficient reached 0.96 to 0.98 , with an average of 0.972 , after ten rolling passes. In a $50 \mathrm{~cm}$ lift thickness of wet sand, the compaction coefficient reached 0.96 to 0.99 , with an average of 0.974 , after 12 rolling passes. The values of both thicknesses were close to or reached the requirement of 0.98 for the compaction coefficient. Therefore, according to the test results, wet aeolian sand in 30 and $50 \mathrm{~cm}$ lift thicknesses can achieve the requirements of OTS as backfill materials.

- When the three types of sand fixation materials in a $15 \mathrm{~cm}$ thickness were rolled ten times, the compaction coefficient reached 0.97 to 0.98 . However, 12 rolling passes were needed for the three types of sand fixation materials in a $30 \mathrm{~cm}$ thickness to reach compaction coefficient values of 0.96 to 0.99 .

- Because the site was in the desert, the moisture in the backfill material easily evaporated when excavated, transported and stacked. Therefore, the water content was controlled at OMC $+5 \%$ to account for the evaporation loss and to maintain moisture at the $\mathrm{OMC}$ during rolling.

- The CBR values of sandstone-gypsum and sandstone-gatch were higher than $20 \%$, indicating that both had high bearing capacity. The CBR values of sandstone and aeolian sand were $5 \%$ to $9 \%$, indicating that both had low bearing capacity.

- Monitoring resistance to wind erosion and test results showed that the sandstone-gatch layer had the strongest resistance against wind erosion. The resistance of the sandstone-gypsum layer to wind erosion was moderate, whereas the sandstone layer had the weakest resistance against wind erosion.

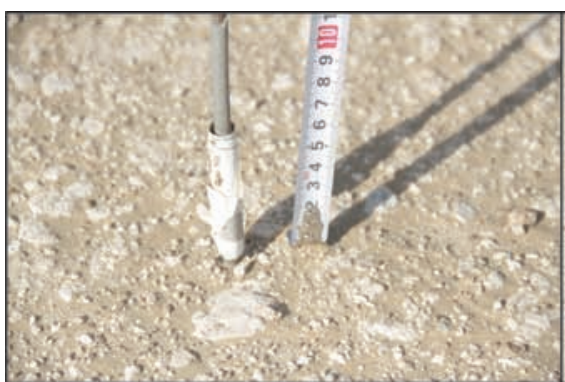

(a)

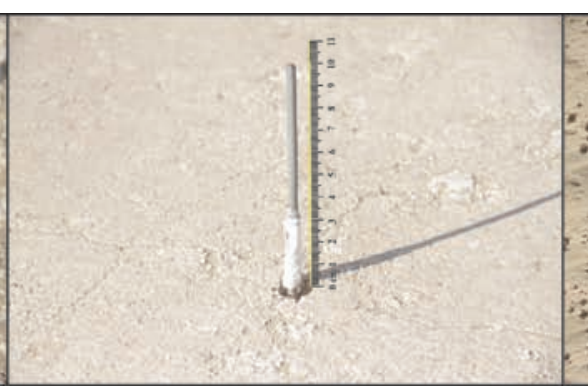

(b)

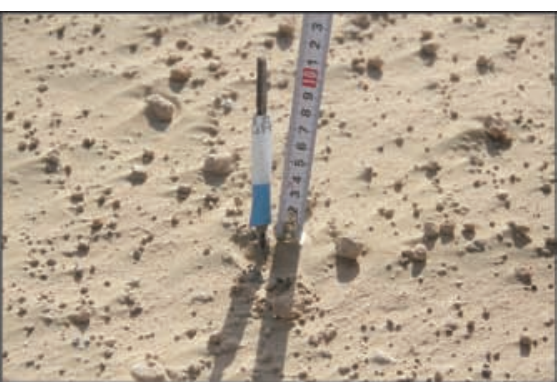

(c)

Figure 11. Resistance of the sand fixation layers to wind erosion (after 6 months on 19 January 2019). (a) Sandstone-gypsum; (b) sandstone-gatch; (c) sandstone 


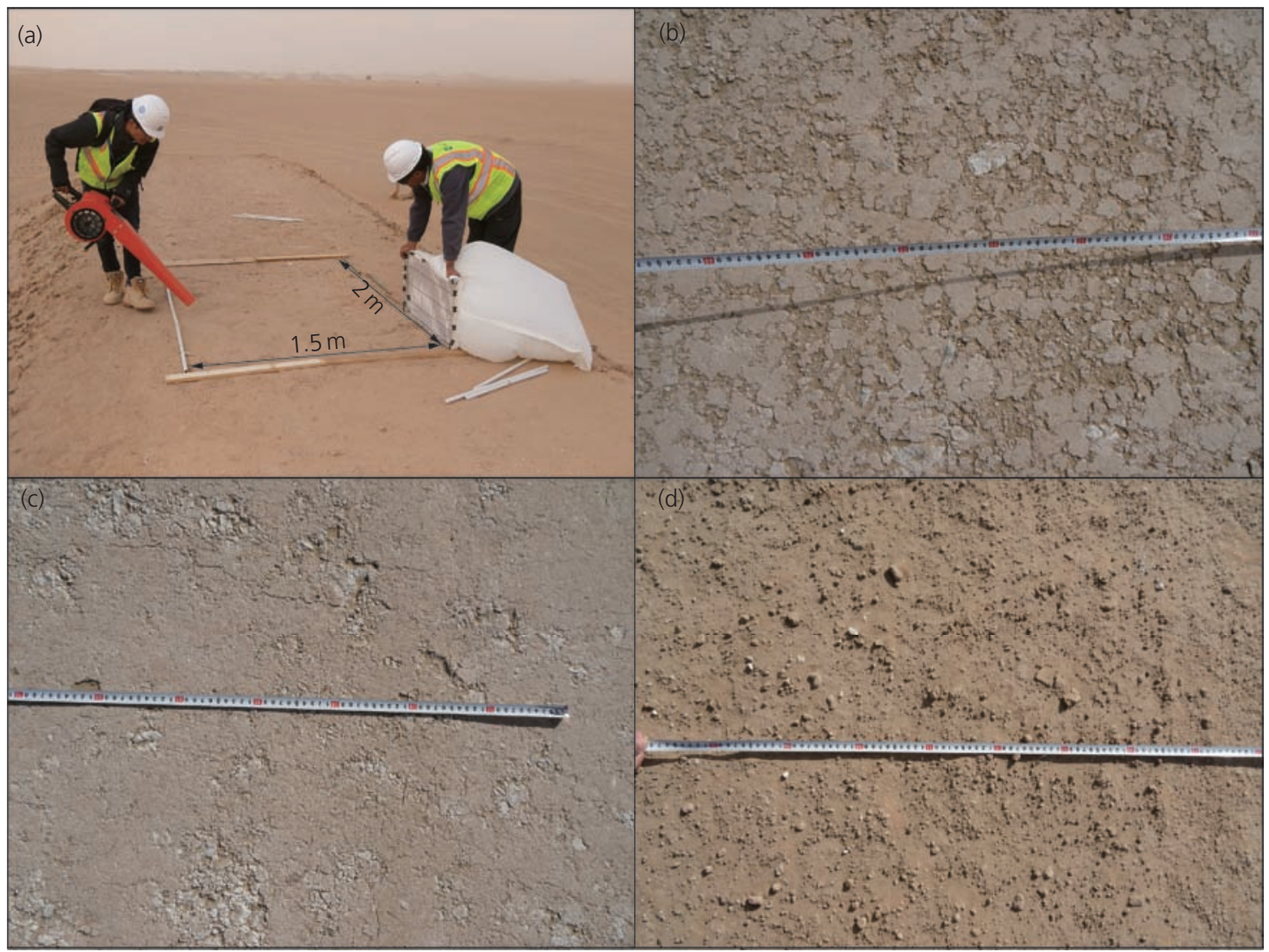

Figure 12. Sand fixation layers after wind erosion tests. (a) In situ wind erosion test; (b) sandstone-gypsum; (c) sandstone-gatch; (d) sandstone

\section{Acknowledgement}

The authors would like to acknowledge the Shanghai Electric Power Generation Engineering Co. (Number 18DK003) scheme, which funded this project.

\section{REFERENCES}

Abu Seif ES, Sonbul AR, Hakami BAH and El-Sawy EK (2016) Experimental study on the utilization of dune sands as a construction material in the area between Jeddah and Mecca, Western Saudi Arabia. Bulletin of Engineering Geology and the Environment 75(3): 1007-1022.

Aiban SA (1994) A study of sand stabilization in eastern Saudi Arabia. Engineering Geology 38(1-2): 65-79.

Albusoda BS and Hussein RS (2013) Bearing capacity of eccentrically loaded square foundation on compacted reinforced dune sand over gypseous soil. Journal of Earth Sciences and Geotechnical Engineering 3(4): 47-62.

Albusoda BS and Salem LA (2012) Stabilization of dune sand by using cement kiln dust (CKD). Journal of Earth Sciences and Geotechnical Engineering 2(1): 131-143.

Al-Sanad HA, Ismael NF and Nayfeh AJ (1993) Geotechnical properties of dune sands in Kuwait. Engineering Geology 34(1-2): 45-52.

Al-Taie AJ, Al-Shakarchi YJ and Mohammed AA (2013) Investigation of geotechnical specifications of sand dune soil: a case study around Baiji in Iraq. IIUM Engineering Journal 14(2): 121-132.

Andavan S and Kumar BM (2020) Case study on soil stabilization by using bitumen emulsions - a review. Materials Today: Proceedings 22(3): 1200-1202.
ASTM (2003) D 1557-12e1: Standard test methods for laboratory compaction characteristics of soil using modified efforts. ASTM International, West Conshohocken, PA, USA.

ASTM (2009) D 4429: Standard test method for CBR (California Bearing Ratio) of soils in place. ASTM International, West Conshohocken, PA, USA.

ASTM (2012) D 698-12e2: Standard test methods for laboratory compaction characteristics of soil using standard effort. ASTM International, West Conshohocken, PA, USA.

ASTM (2017a) D 2487-17e1: Standard practice for classification of soils for engineering purposes (Unified Soil Classification System). ASTM International, West Conshohocken, PA, USA.

ASTM (2017b) D 6938-17a: Standard test methods for in-place density and water content of soil and soil-aggregate by nuclear methods (shallow depth). ASTM International, West Conshohocken, PA, USA. Cherrak M, Morsli M, Boutemeur R and Bali A (2015) Valorization of the use of calcareous tuff and dune sand in Saharan road design. Journal of Civil Engineering and Architecture 9: 665-676.

Edgell HS (2006) Arabian Deserts. Springer, Dordrecht, the Netherlands. Elipe MGM and López-Querol S (2014) Aeolian sands: characterization, options of improvement and possible employment in construction the state-of-the-art. Construction and Building Materials 73: 728-739.

Fattah MY, Joni HH and Al-Dulaimy ASA (2016) Compaction and collapse characteristics of dune sand stabilized with lime-silica fume mix. Earth Sciences Research Journal 20(2): I1-I8.

Gholipoor Noroozi A, Kouravand S and Boveiri M (2015) A review of using the waste in soil stabilization. International Journal of Engineering Trends and Technology 21(1): 33-37. 
Hall MR, Lindsay R and Krayenhoff M (eds) (2012) Modern Earth Buildings: Materials, Engineering, Constructions and Applications. Woodhead Publishing, Cambridge, UK.

Ismael NF, Mollah MA and Al-Khalidi O (1986) Geotechnical properties of cemented soils in Kuwait. Australian Road Research 16(2): 94-104.

Ministry of Transport of the People's Republic of China (2008) JTG/T D31-2008: Guidelines for highway design and construction in sandy desert area. Ministry of Transport of the People's Republic of China, Beijing, China.

Kumar P, Das V, Gupta A and Ameta NK (2016) Stabilization of dune sand mixed with plastic (LDPE) waste strips for design of flexible pavement in construction of roads. American Journal of Engineering Research 5(11): 315-320.

Matcon Testing Laboratory (2018) Geotechnical Investigation Report - rev3 for PT1 Solar Field. Matcon Testing Laboratory, Dubai, UAE.

Munkholm LJ and Kay BD (2002) Effect of water regime on aggregatetensile strength, rupture energy, and friability. Soil Science Society of America Journal 66(3): 702-709.

Munro R (2017) Hydrocompaction. In Encyclopedia of Engineering Geology. Encyclopedia of Earth Sciences Series (Bobrowsky P and Marker B (eds)). Springer, Cham, Switzerland.

Niu BC, Qu JJ, Zhang XC et al. (2019) Quantifying provenance of reservoir sediment using multiple composite fingerprints in an arid region experiencing both wind and water erosion. Geomorphology 332: $112-121$.

Olmstead K and Tessler M (2008) Urban development in the Arabian Peninsula. The Journal of the International Institute 16(1): article 6.

Padmakumar GP, Srinivas K, Uday KV et al. (2012) Characterization of aeolian sands from Indian desert. Engineering Geology 139-140: $38-49$.
Prasad J and Purohit DGM (2017) A study on shear strength for dune sand reinforced with shredded waste tyres. American Journal of Engineering Research 6(10): 221-226.

Rahman MA and Ahmed A (2017) Use of silica fume in stabilizing cement-dune sand for highway materials. American Journal of Civil Engineering 5(1): 41-49.

Ren HM, Zeng XD and Shi GP (2018) Research on the wet compaction technology for aeolian sand subgrade of MengHua Heavy-Load Railway. Journal of Lanzhou Jiaotong University 37(6): 1-6 (in Chinese with English summary).

Rogers CDF, Dijkstra TA and Smalley IJ (1994) Hydroconsolidation and subsidence of loess: studies from China, Russia, North America and Europe. Engineering Geology 37(2): 83-113.

Stipho AS (1984) Soil conditions and foundation problems in the desert region of the Middle East. In First International Conference on Case Histories in Geotechnical Engineering: Theme I - Case Histories in Foundations of Structures and Failure Records. Missouri University of Science and Technology, Rolla, MO, USA, article 53.

Tiwari SK, Sharma JP and Yadav JS (2016) Behaviour of dune sand and its stabilization techniques. Journal of Advanced Research in Applied Mechanics 19(1): 1-15.

Yao ZY, Chen GT, Han ZW and Shao GS (2001) Mechanical properties of aeolian sandy soil in central Taklimakan Desert. Journal of Desert Research 21(1): 31-36 (in Chinese with English summary).

Zhang H, Liu J, Hu JY, She XS and Jia XX (2015) Research on engineering characteristics of aeolian sand in desert region of Maowusu in northern Shaanxi. Journal of Hefei University of Technology (Natural Science) 38(08): 1103-1108 (in Chinese with English summary).

Zhang H, Wang ZY and Liu RX (2013) Research on dynamic compaction characteristics of Aeolian sand in desert region of Keerqin. Rock and Soil Mechanics 34(Supp2): 100-104 (in Chinese with English summary).

\section{How can you contribute?}

To discuss this paper, please submit up to 500 words to the editor at journals@ice.org.uk. Your contribution will be forwarded to the author(s) for a reply and, if considered appropriate by the editorial board, it will be published as a discussion in a future issue of the journal. 